
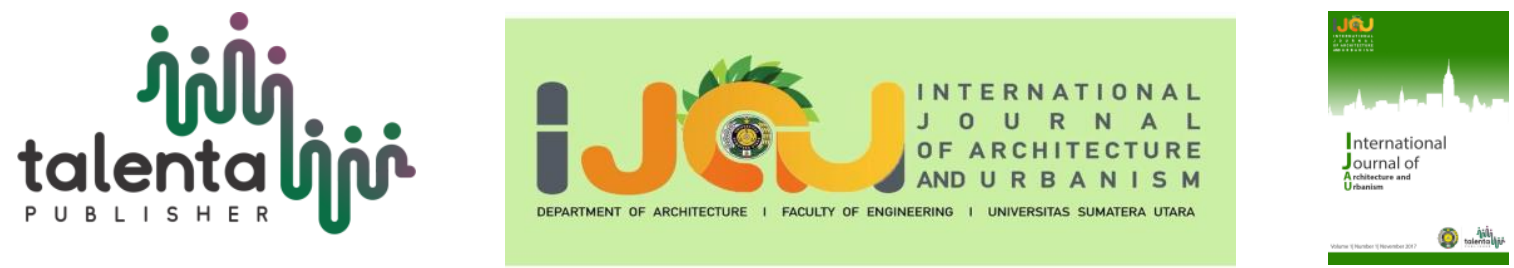

\title{
A Study on the Application of Solar Panel Technology in Low-Income Residential Housing in Deli Serdang Regency
}

\author{
Dicky Andrea Sembiring ${ }^{*}$, Ahmad Mansuri' ${ }^{1}$, Ferry Rahmat Astianta \\ Bukit $^{2}$, Malinda Sari Sembiring ${ }^{3}$ \\ ${ }^{1}$ Department of Architecture, Faculty of Engineering, Universitas Sumatera Utara \\ ${ }^{2}$ Department of Electrical Engineering, Faculty of Engineering, Universitas Sumatera Utara \\ ${ }^{3}$ Faculty of Economics and Business, Universitas Sumatera Utara
}

\begin{abstract}
The need for energy use, especially electrical energy continues to increase from year to year. One of the sectors that consume the largest electrical energy is the household sector which consumes about $27 \%$ of the total energy consumption of all sectors. The main energy source in Indonesia at this time still comes from fossil energy, although the government has tried to develop various renewable energy sources for the future. Solar energy is one of the renewable energies that is quite potential for Indonesia considering the level of solar radiation in Indonesia is quite high throughout the year. The selection of subsidized housing as the object of research is due to the existence of clear regulations and the number which also continues to increase every year. Through the collection of physical data on the research location, such as analysis of shadows, roof structure, solar irradiation data, average electric power usage, the average solar energy requirement of the subsidized housing will be obtained. Furthermore, by calculating the economic value, it will be obtained how the description of the possibility of applying solar energy to subsidized housing will be obtained. If possible, the application of solar energy in subsidized housing can help government programs to use renewable energy and reduce the use of fossil energy
\end{abstract}

Keyword: low income housing, rooftop solar technology, renewable energy

Received 26 October 2021 | Revised 27 November 2021 | Accepted 27 November 2021

\section{Introduction}

The electricity sector has become a basic need for the world today, electricity does not only play a role in the production sector, but also the needs of daily life. Therefore many studies conclude that electricity is the foundation for the development of a country whose end product is an increase in people's welfare [1].

\footnotetext{
*Corresponding author at: Department of Architecture, Faculty of Engineering, Universitas Sumatera Utara, Perpustakaan st. Building J07, Medan, 20155, Indonesia

E-mail address: dickyandrea@usu.ac.id
} 
Buildings have a high percentage of electricity consumption of total electricity consumption worldwide. Where households themselves consume $27 \%$ of the total energy [2]. In the household there are many electronic equipment which in its use consumes electrical energy. The tendency for this high value is due to the lack of control of home users in using electronic devices at home and the absence of an integrated system used to control electronic equipment in the household.

The higher the economic growth of an area, the higher the use of energy consumption in that area. This is because every activity of the community requires energy, while on the other hand energy sources are running low, as is the energy used every day. The less energy sources, it will cause an energy crisis throughout Indonesia. This condition occurs because the demand for energy is increasing, while the availability of the amount of energy is getting smaller. This causes the value of energy to be higher day by day so that effective and efficient energy use is needed [3].

To meet this demand for electricity, according to the National Energy Policy, various alternative energies including renewable energy must be developed, including geothermal, micro-hydro, solar, wind, oceanic, biomass and nuclear, which are targeted to reach more than $17 \%$ of the national primary energy share [4].

To meet the demand for electricity in 2025 , renewable energy resources that can provide significant support are geothermal, biomass (through waste, waste, gasification and biofuels) and solar through PLTS. Wind power according to Indonesian conditions is very limited, while marine power is technically and economically difficult to develop on a large scale [5].

Indonesia is a country located on the equator, which means that Indonesia gets high and constant sunlight throughout the year. The potential for solar energy that can be obtained in Indonesia is around $4.8 \mathrm{KWh} / \mathrm{m} 2$ per day. In 2025 the government has a target of the number of PLTS installed at $0.87 \mathrm{GW}$ or around $50 \mathrm{MWp}$ /year. This implies that the market potential for solar energy is actually quite high [6].

From a policy perspective, the use of solar energy has also received support from the government, the Rooftop PLTS program by the Ministry of Energy and Mineral Resources, facilitating the regulation of the installation of PLTS in residential homes through the Minister of Energy and Mineral Resources Regulation No. 13 of 2019. Through this regulation, residential homes are allowed to build PLTS private roof by following written procedures [7].

Judging from what has been said above, the use of solar energy as an energy source in the housing sector, especially in low-income housing, will certainly have an impact on the government's program to use renewable energy. Considering that the construction of subsidized houses follows government regulations and the number of subsidized housing developments 
continues to increase. An in-depth study of the possibility of implementing the rooftop solar PV idea in low-income housing will certainly provide an overview of its possible application.

\section{Literature Review}

The discovery of electric power from sunlight was pioneered by Alexandre - Edmund Becquerel a French physicist in 1839. He conducted experiments by irradiating 2 electrodes wrapped with various kinds of light. The electrodes were wrapped with light-sensitive materials, namely $\mathrm{AgCl}$ and $\mathrm{AgBr}$. The result was that the electric power increased when the light intensity was increased. [8]

\subsection{Types of Solar Panels}

1. Monocrystalline

This panel has the highest efficiency, the efficiency value can be $15 \%$. In addition, this type of panel is the most common type produced today. However, this panel has the disadvantage that its effectiveness will decrease if the weather conditions are a bit cloudy.

\section{Polycrystalline}

Formed from silicon crystals that are melted and molded into a square shape. The resulting efficiency is about $13-16 \%$. This type of panel is the most widely circulated in the market today and the price is also cheaper when compared to monocrystalline panels.

\section{Thin Film Solar Cell (TFSC)}

This panel consists of layers of microcrystalline and amorphous silicon. The efficiency of the module can reach $8.5 \%$ so that compared to the other two types of panels, this is the type of panel with the lowest efficiency. But the advantage is the thinness of this material, so its use can be more flexible, not only limited to the roof, but can be applied to other parts of the building. The weakness remains the same, namely the efficiency will be greatly reduced if the weather conditions are a bit cloudy [9].

\subsection{Rooftop Solar Power Plant (PLTS) Components}

The design of the rooftop PV mini-grid system discussed is on-grid roof PV mini-grid without using batteries. In simple terms, the PLTS system consists of main components with the following configuration (Figure1): 


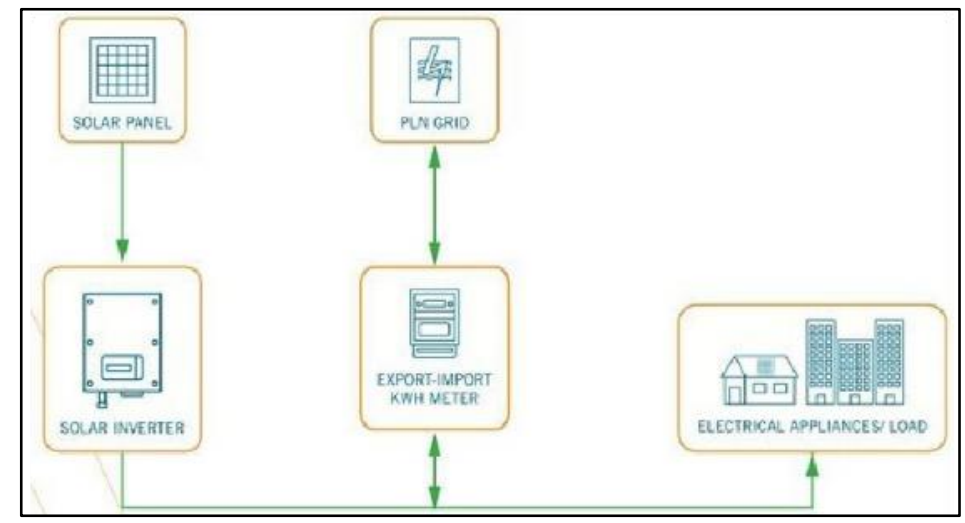

Figure 1. Rooftop PLTS System

\section{Panel Surya/Solar Panel}

A series of photovoltaic solar modules that convert solar radiation into electric power. Electric power generated in the form of DC voltage

2. Inverter

A tool unit that functions to convert DC voltage input directly from photovoltaic solar modules into AC voltage output.

\section{Eksport-Import KWh Meter}

KWh Meter which functions to measure the inflow of electricity from the PLN distribution network to customers (imports), as well as measuring the outflow of electricity from the rooftop PLTS system to the PLN distribution network (exports).

\section{PLN Grid}

The PLN electricity network serves to deliver electricity from the transmission network to customers. For Rooftop PLTS customers, the PLN distribution network is also a medium for exporting unused PLTS electricity.

5. Load / Electrical Appliances

Are the end users of electricity, both generated by PLTS and imported from the PLN network. For example, electrical equipment at home or office.

In addition to the above components, there are supporting components: (1) AC distribution panel which functions to divide the inverter output load according to the capacity of each load; (2) DC breaker which functions as a breaker from the solar panel to the inverter, to avoid a short circuit.

\subsection{The Potential of Solar Energy in Indonesia}

Indonesia is always passed by the sun every day with sufficient intensity of solar radiation, which ranges from $2.56 \mathrm{kWh} / \mathrm{m} 2$ to $5.75 \mathrm{kWh} / \mathrm{m} 2$, therefore solar power generation in Indonesia needs to be developed further. The following is a list of the intensity of solar radiation in Indonesia (Table 1). 
Table 1. Intensity of Solar Radiation in Indonesia

\begin{tabular}{|c|c|c|c|c|}
\hline Province & Location & $\begin{array}{c}\text { Measurement } \\
\text { Year }\end{array}$ & $\begin{array}{c}\text { Geographical } \\
\text { Position }\end{array}$ & $\begin{array}{l}\text { Radiation } \\
\text { Intensity } \\
\left(\mathrm{Wh} / \mathrm{m}^{2}\right)\end{array}$ \\
\hline Aceh & Pidie & 1980 & $4^{\circ} 15^{\prime} \mathrm{LS} ; 96^{\circ} 52^{\prime} \mathrm{BT}$ & 4.097 \\
\hline Sumsel & Ogan Komering Ulu & $1979-1981$ & $3^{\circ} 10^{\prime} \mathrm{LS} ; 104^{\circ} 42^{\prime} \mathrm{BT}$ & 4.950 \\
\hline Lampung & Kab. Lampung Selatan & 1972-1979 & $4^{\circ} 28^{\prime} \mathrm{LS} ; 105^{\circ} 48^{\prime} \mathrm{BT}$ & 5.234 \\
\hline DKI Jakarta & Jakarta Utara & $1965-1981$ & $6^{\circ} 11^{\prime} \mathrm{LS} ; 106^{\circ} 05^{\prime} \mathrm{BT}$ & 4.187 \\
\hline \multirow[t]{2}{*}{ Banten } & Tangerang & 1980 & $6^{\circ} 07^{\prime} \mathrm{LS} ; 106^{\circ} 30^{\prime} \mathrm{BT}$ & 4.324 \\
\hline & Lebak & 1991-1995 & $6^{\circ} 11^{\prime} \mathrm{LS} ; 106^{\circ} 30^{\prime} \mathrm{BT}$ & 4.446 \\
\hline \multirow[t]{2}{*}{ Jawa Barat } & Bogor & 1980 & $6^{\circ} 11^{\prime} \mathrm{LS} ; 106^{\circ} 39^{\prime} \mathrm{BT}$ & 2.558 \\
\hline & Bandung & 1980 & $6^{\circ} 56^{\prime} \mathrm{LS} ; 107^{\circ} 38^{\prime} \mathrm{BT}$ & 4.149 \\
\hline Jawa Tengah & Semarang & 1979-1981 & $6^{\circ} 59^{\prime} \mathrm{LS} ; 110^{\circ} 23^{\prime} \mathrm{BT}$ & 5.488 \\
\hline DI Yogyakarta & Yogyakarta & 1980 & $7^{\circ} 37^{\prime} \mathrm{LS} ; 110^{\circ} 01^{\prime} \mathrm{BT}$ & 4.500 \\
\hline Jawa Timur & Pacitan & 1980 & $7^{\circ} 18^{\prime} \mathrm{LS} ; 112^{\circ} 42^{\prime} \mathrm{BT}$ & 4.300 \\
\hline KalBar & Pontianak & 1991-1993 & $4^{\circ} 36^{\prime} \mathrm{LS} ; 9^{\circ} 11^{\prime} \mathrm{BT}$ & 4.552 \\
\hline KalTim & Kabupaten Berau & 1991-1995 & $0^{\circ} 32^{\prime} \mathrm{LU} ; 117^{\circ} 52^{\prime} \mathrm{BT}$ & 4.172 \\
\hline \multirow[t]{2}{*}{ KalSel } & Kota Baru & 1979-1981 & $3^{\circ} 27^{\prime} \mathrm{LS} ; 114^{\circ} 50^{\prime} \mathrm{BT}$ & 4.796 \\
\hline & & 1991-1995 & $3^{\circ} 25^{\prime} \mathrm{LS} ; 114^{\circ} 41^{\prime} \mathrm{BT}$ & 4.573 \\
\hline Gorontalo & Gorontalo & 1991-1995 & $1^{\circ} 32^{\prime} \mathrm{LU} ; 124^{\circ} 55^{\prime} \mathrm{BT}$ & 4.911 \\
\hline Sulteng & Donggala & 1991-1994 & $0^{\circ} 57^{\prime} \mathrm{LS} ; 120^{\circ} 0^{\prime} \mathrm{BT}$ & 5.512 \\
\hline Papua & Jayapura & 1992-1994 & $8^{\circ} 37^{\prime} \mathrm{LS} ; 122^{\circ} 12^{\prime} \mathrm{BT}$ & 5.720 \\
\hline NTB & Kabupaten Sumbawa & 1991-1995 & $9^{\circ} 37^{\prime} \mathrm{LS} ; 120^{\circ} 16^{\prime} \mathrm{BT}$ & 5.747 \\
\hline NTT & Ngada & $1975-1978$ & $10^{\circ} 9^{\prime} \mathrm{LS} ; 123^{\circ} 36^{\prime} \mathrm{BT}$ & 5.117 \\
\hline
\end{tabular}

\subsection{Low Income Society}

Low-income people can be defined as people who have limited purchasing power so they need government support to get a house. If viewed from this definition, it can be said that the government is obliged to assist the community in this group to obtain housing [10].

This grouping of low-income people is determined by the income limit criteria which are directly related to the location of the purchase price of the house. For the type of low-income community housing in question, it can be divided into 3 types, namely: (1) General Flats; (2) Land House; (3) Self-build House. The selling price of these low-income community houses varies for various regions in Indonesia (Table 2) [11].

Table 2. Limitation of the selling price of land house

\begin{tabular}{clc}
\hline No & \multicolumn{1}{c}{ Region } & $\begin{array}{c}\text { Highest Selling Price } \\
\text { (Rp.) }\end{array}$ \\
\hline $1 \quad \begin{array}{l}\text { Daerah Jawa (except Jakarta, Bogor, Depok, } \\
\text { Tangerang, Bekasi) dan Sumatera (except Kep. Riau, } \\
\text { Bangka Belitung, Kepulauan Mentawai) }\end{array}$ & 150.500 .000 \\
\end{tabular}




\begin{tabular}{clr}
\hline No & \multicolumn{1}{c}{ Region } & $\begin{array}{c}\text { Highest Selling Price } \\
\text { (Rp.) }\end{array}$ \\
\hline 2 & $\begin{array}{l}\text { Daerah Kalimantan (except Kabupaten Murung Raya } \\
\text { dan Kabupaten Mahakam Ulu) }\end{array}$ & 164.500 .000 \\
$3 \quad \begin{array}{l}\text { Daerah Sulawesi, Bangka Belitung, Kepulauan } \\
\text { Mentawai, dan Kepulauan Riau (except Kepulauan }\end{array}$ & 166.500 .000 \\
Anambas) & $\begin{array}{l}\text { Daerah Maluku, Maluku Utara, Bali dan Nusa } \\
\text { Tenggara, Jabodetabek (Jakarta, Bogor, Depok, } \\
\text { Tangerang, Bekasi), Kepulauan Anambas, Kabupaten } \\
\text { Murung Raya, dan Kabupaten Mahakam Ulu }\end{array}$ \\
& \begin{tabular}{l} 
Daerah Papua and Papua Barat \\
\hline
\end{tabular}
\end{tabular}

\section{Methodology}

The research methodology used is a quantitative research. The initial data collection, through observation and interviews, will produce measurable data such as solar irradiation data, the effective area of the roof, the amount of electricity costs and so on. This data will later be processed to determine the need for PLTS roofs for the subsidized houses being investigated. For house sampling, it will be carried out by considering the principle of conformity, where researchers will look at the economic conditions that are visible from the owner of the house. After the analysis is carried out, the costs incurred will be calculated as well as an economic analysis related to the economic value that can be generated by the rooftop solar power plant (Figure 3).

\subsection{Research Site}

Research on the application of solar panel technology in low-income housing will be carried out on (Table 3):

Table 3. Research Site

\begin{tabular}{llll}
\hline No & \multicolumn{1}{c}{ Research Location } & Sampel Quantity & \multicolumn{1}{c}{ Description } \\
\hline 1 & Sehati Residence Housing & 10 & The sample taken is \\
& (Jl. Johar, Sei Beras Sekata, & related to the amount \\
Kec. Sunggal, Kabupaten & & of electricity bills \\
Deli Serdang) & per month. \\
\hline
\end{tabular}

For more details, the research location is described in the image below (Figure 2). 


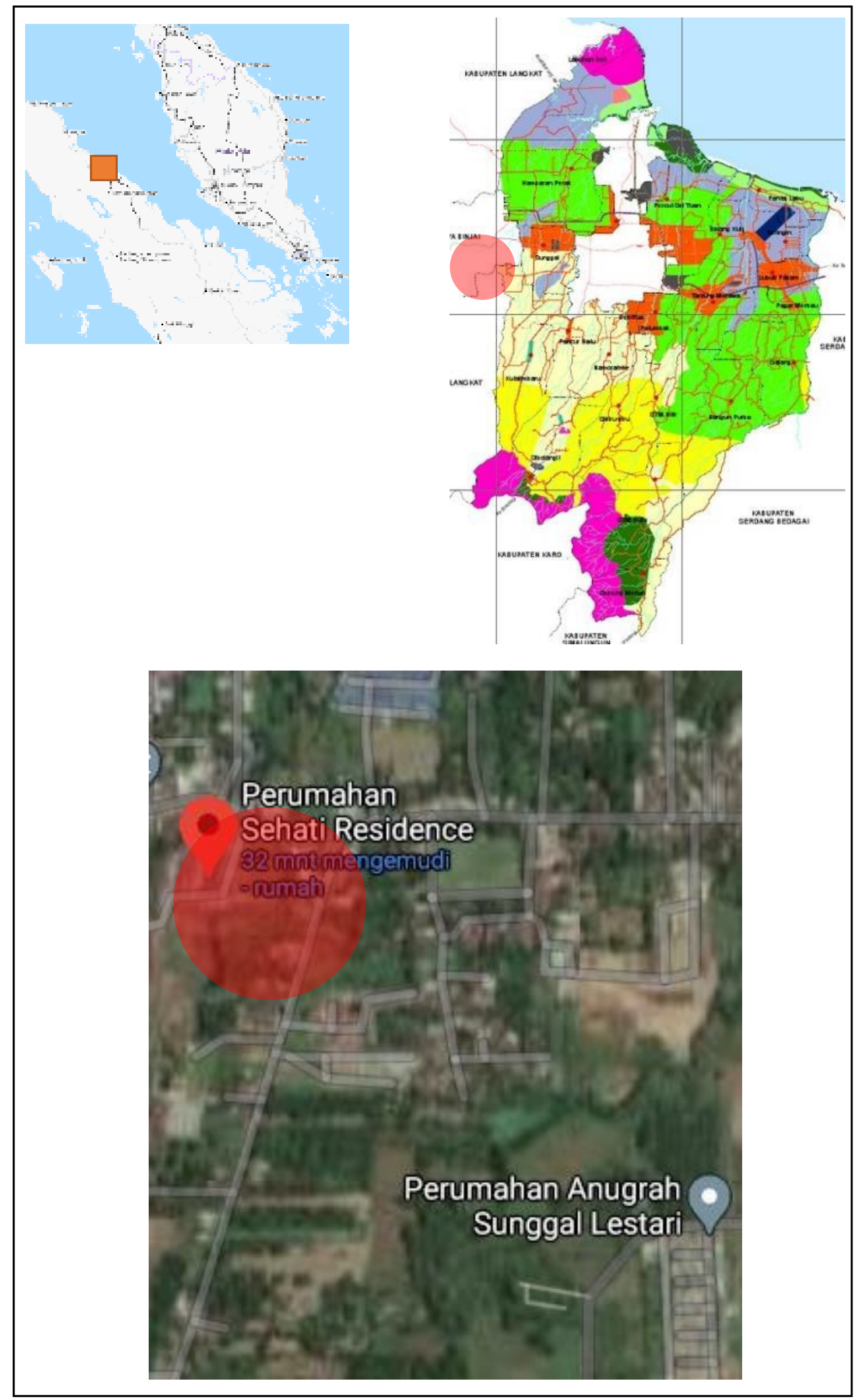

Figure 2. Research Site 


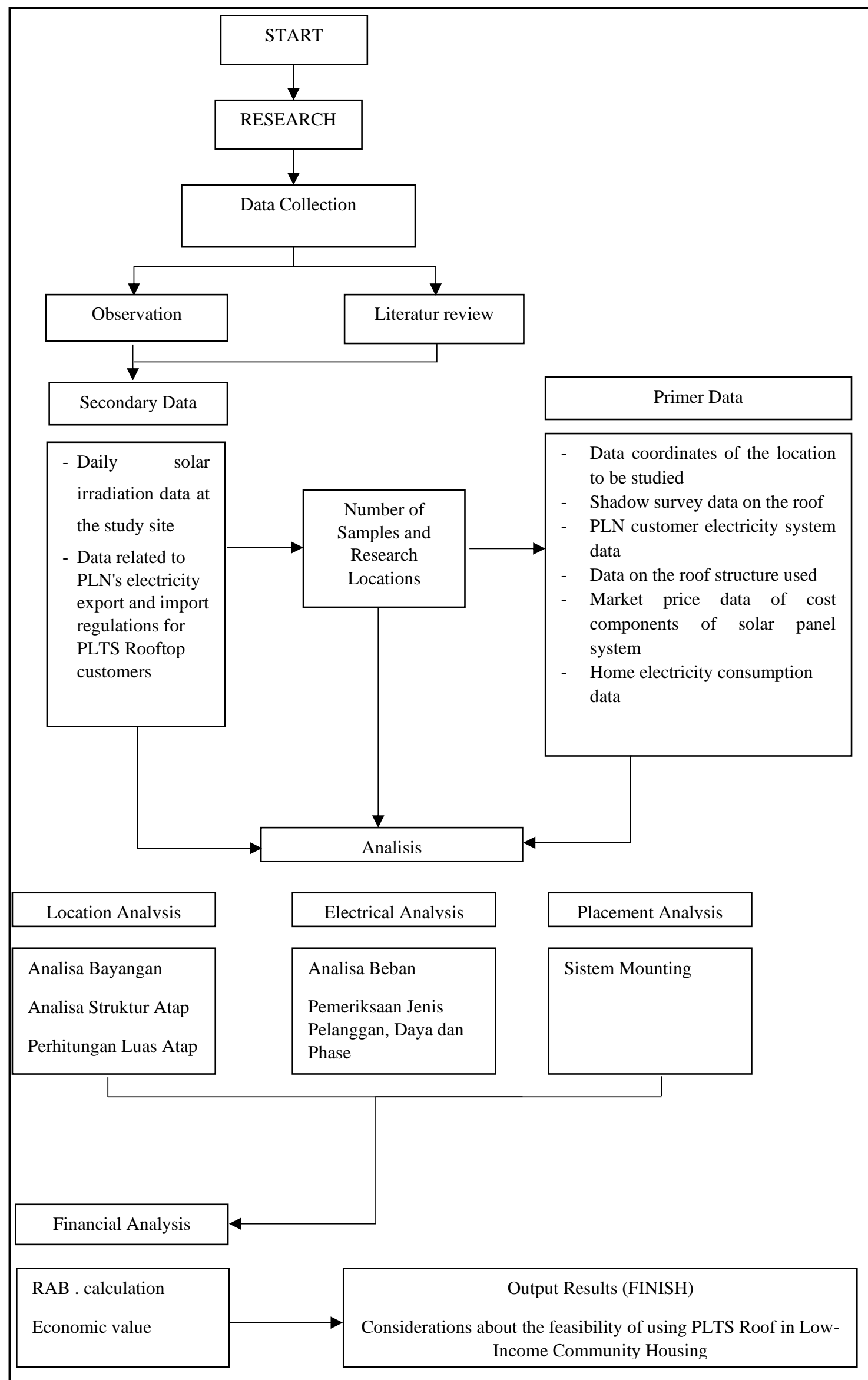

Figure 3. Research Flowchart 


\section{$4 \quad$ Result and Discussion}

\subsection{Shadow Analysis}

Based on the simulations carried out above, it is known that if it is in accordance with the existing conditions at the research site, the roof of the building will be effectively exposed to sunlight starting from $10.00 \mathrm{WIB}-15.30 \mathrm{WIB}$, or about 7 hours 30 minutes.

Meanwhile, if adjustments are made to the direction of the sun, by changing the direction of the front of the roof to be north-south, then the roof will be effectively exposed to sunlight starting from 08.00 WIB - 17.00 WIB, or about 9 hours (Figure 4).

Given that this condition can actually be achieved if there is a rule that recommends that the direction of the roof facing the subsidized housing faces north-south, the writer will use subsidized housing with the roof facing north-south as the object to be investigated. This will certainly be able to show the actual conditions related to the feasibility of using solar panels in subsidized housing.

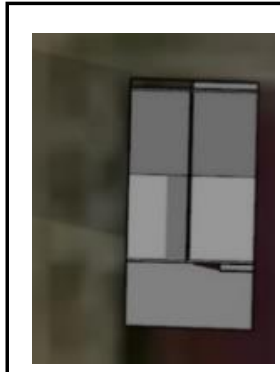

07.00 WIB

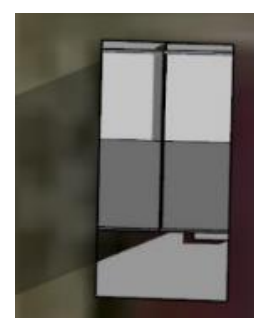

07.00 WIB

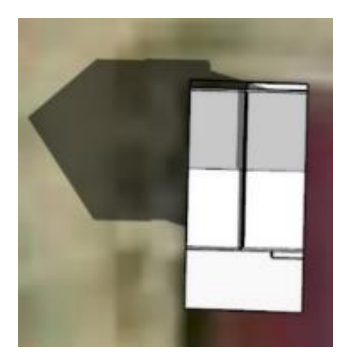

09.00 WIB

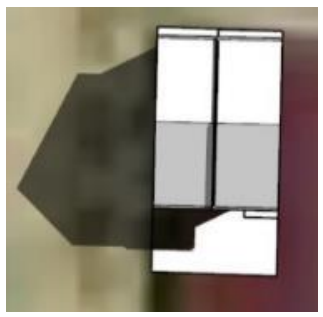

09.00 WIB

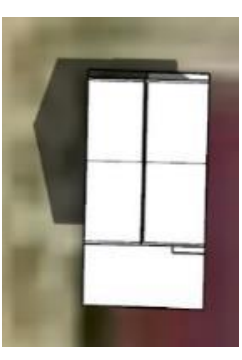

11.00 WIB

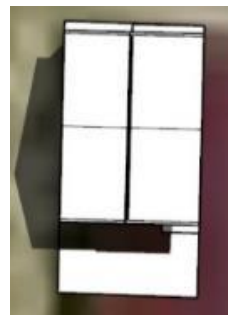

11.00 WIB

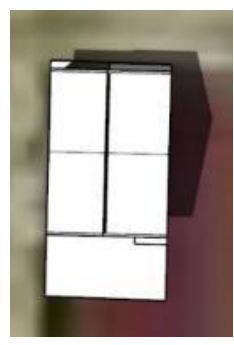

14.00 WIB

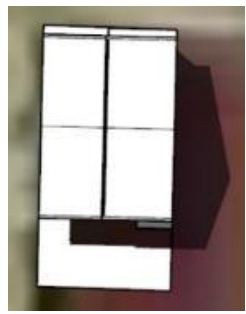

14.00 WIB

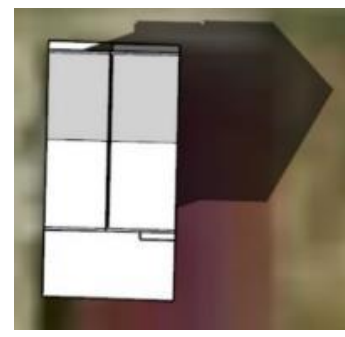

16.00 WIB

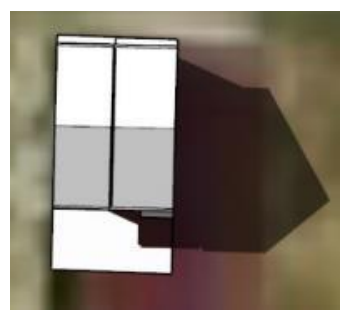

16.00 WIB

Figure 4. Shadow Analysis on subsidized houses according to field conditions

\subsection{Roof Area Calculation}

To calculate the effective area, only the part of the roof that is right at the top of the building will be used, not including the eaves on the front and back of the building. From these calculations, it is known that the roof area that can be used for the placement of solar panels is $47.93 \mathrm{~m} 2$ (Figure 5). 


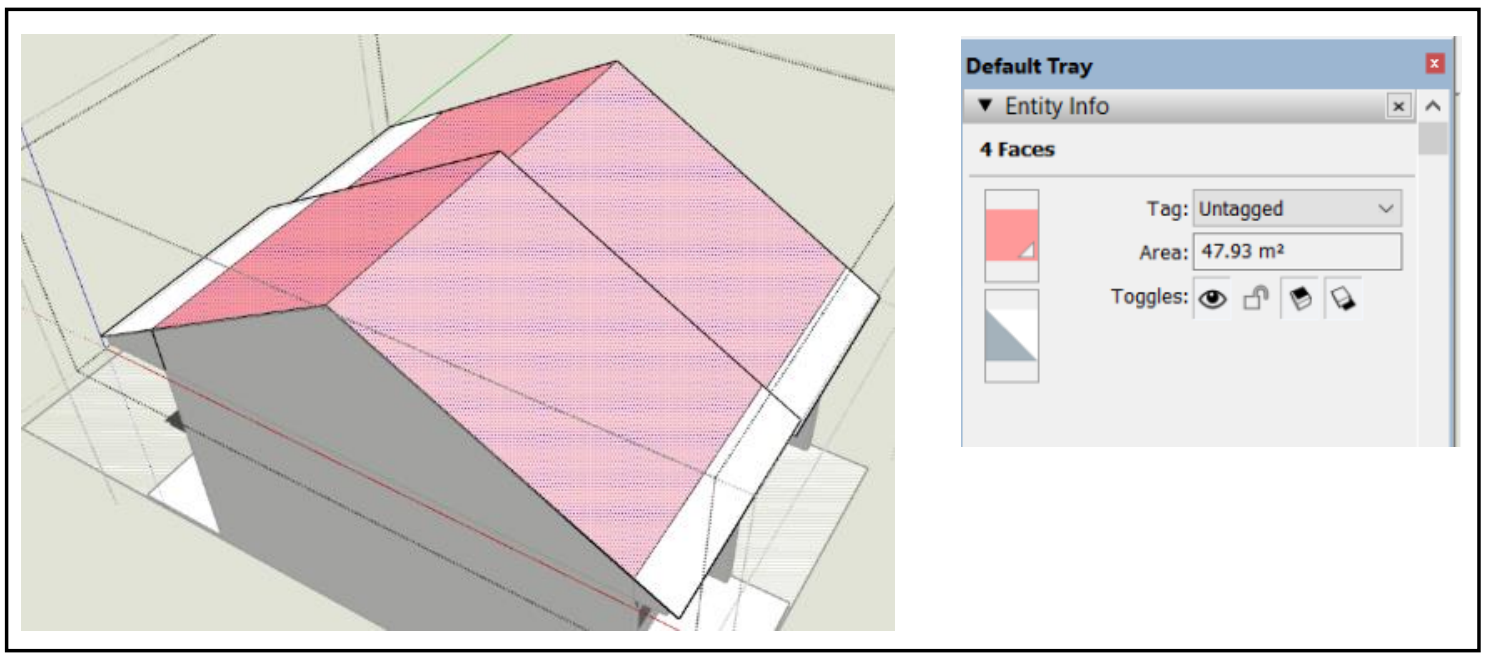

Figure 5. Effective roof area

\subsection{Observation of Electric Power Usage}

If averaged, it will be obtained the value of Rp. 131,000 for the amount of the monthly bill. If we convert it, the daily electricity consumption is 3 Kilo Watt, considering that the basic electricity tariff for a house with a 1300 Watt meter is Rp. 1,444,7.

Based on the Regulation of the Minister of Energy and Mineral Resources No. 49 of 2018 jo. Minister of Energy and Mineral Resources Regulation No. 13 of 2019, jo. Minister of Energy and Mineral Resources Regulation No. 16 of 2019, we can export our excess electricity to PLN with a value of $65 \%$ of the Basic Electricity Tariff.

This means that if we want to use solar panels on the roof of our buildings, the most optimal concept is to first meet our electricity needs during daytime use, then the rest for export. In addition, considering that this is a subsidized residential house, the use of batteries to store electrical energy from solar panels will be avoided, because the price of batteries is quite high when compared to the economic capacity of prospective buyers of this subsidized house (Table 4).

Table 4. Monthly Electricity Bill

\begin{tabular}{clc}
\hline No & House Number & Monthly Electricity Bill (Rp) \\
\hline 1 & B1 & 150.000 \\
2 & B10 & 120.000 \\
3 & B11 & 120.000 \\
4 & B12 & 130.000 \\
5 & B15 & 100.000 \\
6 & B16 & 90.000 \\
7 & B25 & 110.000 \\
8 & B26 & 170.000 \\
9 & B29 & 200.000 \\
10 & B30 & 120.000 \\
\hline
\end{tabular}




\subsection{Rooftop PLTS Installation Analysis}

After knowing the need for using electrical energy during the day, it is necessary to calculate the optimal capacity of the solar panel system that we will install. To calculate this optimal capacity, we need the average daily energy data and solar irradiation data. Solar irradiation data can be obtained on the website: https://globalsolaratlas. The calculation of the optimal capacity of the solar panel system is as follows (Figure 6).

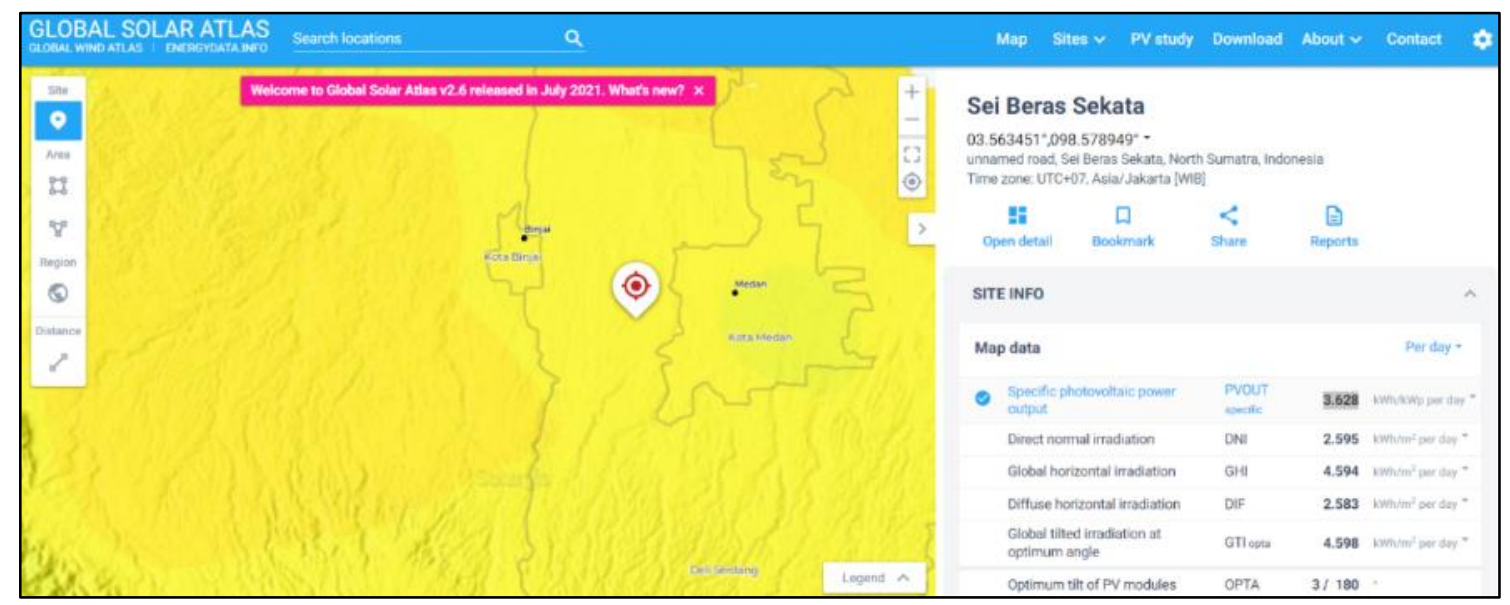

Figure 6. Daily solar irradiation data at the research site

Optimum solar panel capacity $=1.5 / 3.628=0.413 \mathrm{KWp}$ or $413 \mathrm{Wp}$. However, based on the Minister of Energy and Mineral Resources Regulation No. 49 of 2018, customers are allowed to install solar panels up to 1300 Watts, according to the connected power.

\section{Peak Power $=$ Optimal Capacity $+25 \%$ x Optimal Capacity}

Peak power $=413+(25 \% \mathrm{x} 413)=516.25 \mathrm{Wp}$.

To anticipate if the weather conditions are a bit cloudy, the tolerance value must be added by about $25 \%$ more, so that the total peak power required is:

Final peak power $=516.25+(516.25 \times 25 \%)=645.31 \mathrm{WP}$ rounded up to $650 \mathrm{WP}$.

$$
\frac{\text { Number of Modules }=\text { Final Peak Power }}{\text { Wp per Module }}
$$

Number of modules $=650 \mathrm{Wp}: 220 \mathrm{Wp}=2.95$ pieces, rounded up into 3 solar panels.

\subsection{Budget Plan for Rooftop PLTS}

Calculation of the estimated cost of making Rooftop PLTS with a capacity of $660 \mathrm{Wp}$ can be seen in the following (Table 5). 
Table 5. Budget plan

\begin{tabular}{|c|c|c|c|c|}
\hline No & Job description & $\begin{array}{l}\text { Unit price } \\
\quad(\mathbf{R p})\end{array}$ & Quantity & $\begin{array}{l}\text { Total Price } \\
\quad(\mathbf{R p})\end{array}$ \\
\hline 1 & $\begin{array}{l}\text { Modul Surya ICASolar ICA220-72M } \\
\text { 220Wp Mono }\end{array}$ & 2.000 .000 & 3 & 6.000 .000 \\
\hline 2 & $\begin{array}{l}\text { Solar inverter ATV320U07N4C, } \\
\text { SCHNEIDER INVERTER 0.75 KW, 380- } \\
500 \mathrm{~V}, 3 \text { PHASES, COMPACT }\end{array}$ & 3.100 .000 & 1 & 3.100 .000 \\
\hline 3 & $\begin{array}{l}\text { The cost of replacing a KWh meter into an } \\
\text { import-export KWh meter }\end{array}$ & 3.000 .000 & 1 & 3.000 .000 \\
\hline 4 & AC distribution panel & 1.000 .000 & 1 & 1.000 .000 \\
\hline 5 & DC breaker & 500.000 & 1 & 500.000 \\
\hline 6 & Installation of solar panels bracket & 2.000 .000 & 1 & 2.000 .000 \\
\hline 7 & SLO management fee & 100.000 & 1 & 100.000 \\
\hline 8 & Power cable and accessories & 1.000 .000 & Ls & 1.000 .000 \\
\hline 9 & $\begin{array}{l}\text { Installation services } \\
\text { TOTAL }\end{array}$ & 2.000 .000 & Ls & $\begin{array}{r}2.000 .000 \\
\mathbf{1 8 . 7 0 0 . 0 0 0}\end{array}$ \\
\hline
\end{tabular}

\subsection{Economic Value Analysis}

Based on the Decree of the Minister of Public Works and Public Housing Number 242/Kpts/M/2020 concerning Income Limits for the Target Group of Subsidized Home Ownership Loans/Financing, Interest Rates/Margins for Subsidized Financing, Length of Subsidy Period and Term of Credit/Financing for Home Ownership, Price Limits Selling Treaded Public Houses and General Flats, Limitation of Land Area and Floor Area Land Houses, Floor Area of Public Flats and the Amount of Subsidy for Housing Down Payment It is known that the highest selling price for subsidized houses in North Sumatra is Rp. 150,500,000, an interest rate of 5\% and a mortgage term of 20 years and a subsidy period of 20 years and a down payment subsidy of Rp. 4,500,000. (Table 6).

Table 6. Subsidy House Installment Value

\begin{tabular}{ccccccc}
\hline $\begin{array}{c}\text { House } \\
\text { Price (Rp) }\end{array}$ & $\begin{array}{c}\% \\
\text { Down } \\
\text { Payment }\end{array}$ & $\begin{array}{c}\text { Down } \\
\text { Payment } \\
(\mathbf{R p})\end{array}$ & $\begin{array}{c}\text { Down } \\
\text { Payment } \\
\text { Subsidy } \\
(\mathbf{R p})\end{array}$ & $\begin{array}{c}\text { Paid Down } \\
\text { payment } \\
(\mathbf{R p})\end{array}$ & Plafon (Rp) & $\begin{array}{c}\text { Installment Period } \\
(\text { Rp) }\end{array}$ \\
\hline 150.500 .000 & 5 & 7.525 .000 & 4.000 .000 & 3.525 .000 & 142.975 .000 & 20 Years \\
\hline
\end{tabular}

If added with the cost of installing PLTS roofs of Rp. 18,700,000, then the calculation will change to (Table 7):

Table 7. The value of the subsidized house installments plus the installation of Rooftop PLTS

\begin{tabular}{ccccccc}
\hline $\begin{array}{c}\text { House } \\
\text { Price (Rp) }\end{array}$ & $\begin{array}{c}\% \\
\text { Down } \\
\text { Payment }\end{array}$ & $\begin{array}{c}\text { Down } \\
\text { Payment } \\
(\text { Rp) }\end{array}$ & $\begin{array}{c}\text { Down } \\
\text { Payment } \\
\text { Subsidy } \\
(\mathbf{R p})\end{array}$ & $\begin{array}{c}\text { Paid Down } \\
\text { payment } \\
(\mathbf{R p})\end{array}$ & Plafon (Rp) & $\begin{array}{c}\text { Installment Period } \\
\text { (Rp) }\end{array}$ \\
\hline 169.200 .000 & 5 & 8.460 .000 & 4.000 .000 & 4.460 .000 & 160.740 .000 & 20 Years \\
\hline
\end{tabular}


If you look at the previous data, where the average electricity bill costs Rp. 131,000 / month, then with the installation of PLTS Roof can save half of these expenses, namely Rp. 65,500. The claim that solar panels can last up to 20 years, which means that during the mortgage period, these solar panels are considered to function properly, because they do not use a battery system, which means that there is no need for battery replacement. However, despite being able to last for 20 years, there is still a difference between the additional installment costs and the

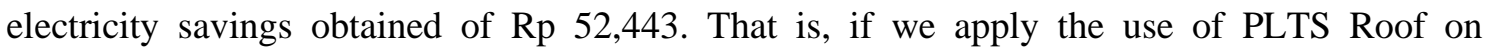
subsidized houses, the prospective buyer will add Rp. 52,443 for the monthly installments, thus increasing their installment burden.

\section{Conclusion}

Although it is not a final conclusion, at this stage of research, several conclusions can be drawn: (1) There is a need for recommendations/regulations/rules that more or less suggest that subsidized residential houses have a roof facing north-south direction, because the use of solar panels will only be optimal if the roof of the building faces north-south; (2) The additional cost required for the installation of solar panels in subsidized residential houses is around Rp. 18,700,000; (3) The additional cost has an impact on additional monthly installments of around Rp. 117,943 . After deducting the electricity cost savings of Rp. 65,000, an additional monthly installment of Rp. 52,443; (4) Based on the results of research conducted, the addition of a rooftop PLTS system still does not provide economic benefits for prospective buyers of subsidized houses, and even adds to the monthly installment burden; (5) However, if viewed from various sides, the use of PLTS Roof on subsidized houses will be able to significantly reduce the use of fossil energy and support government programs for the use of renewable energy; (6) There are several things that the Government can do to support the use of Rooftop PLTS on subsidized houses, starting from reducing import duties for solar panel products, supporting the domestic solar panel industry, or providing a new subsidy scheme for the use of Rooftop PLTS on subsidized homes.

\section{REFERENCES}

[1] Adam. L, "The Roles and Problems of Infrastructure in Indonesia". Economics and Finance in Indonesia, 60 (1), pp.105-126. 2012

[2] Saptono. H D, "Analisis Kebutuhan Energi Kalor pada Industri Tahu," Thesis, Universitas Muhammadiyah Surakarta, Surakarta, Indonesia, 2010.

[3] Kartika Siska Ayu, "Analisis Konsumsi Energi Dan Program Konservasi Energi (Studi Kasus: Gedung Perkantoran Dan Kompleks Perumahan TI)", Sebatik, 1410-3737, pp.4151. 2016.

[4] Indonesia. Regulation of The Minister of Energy and Mineral Resources of The Republic of Indonesia Number 5 of 2017 on National Energy Policy. Jakarta; 2017. 
[5] Boedoyo. Mohamad. Sidik, "Potensi Dan Peranan Plts Sebagai Energi Alternatif Masa Depan Di Indonesia", Jurnal Sains dan Teknologi Indonesia, Vol. 14, No. 2, Agustus 2012, pp.146-152. 2012.

[6] Minister of Energy and Mineral Resources of The Republic of Indonesia, Matahari Untuk PLTS di Indonesia. Jakarta: 2012. [Online]. Available from, https://www.esdm.go.id/id/media-center/arsip-berita/matahari-untuk-plts-di-indonesia. [Accesed: Nov, 7, 2021].

[7] Indonesia. Regulation of The Minister of Energy and Mineral Resources of The Republic of Indonesia Number 13 of 2019 on The Use Of A Roof Solar Power Generating System By Consumers of PT Perusahaan Listrik Negara (Persero). Jakarta; 2019.

[8] Sartika. Resa Eka Ayu, "Penemuan yang Mengubah Dunia: Panel Surya, demi Energi Lebih Bersih". sainskompas.com, para. 1, June. 20, 2019 Available: https://sains.kompas.com/read/2019/06/20/213747123/penemuan-yang-mengubah-duniapanel-surya-demi-energi-lebih-bersih?page=all. [Accesed: October. 13, 2021]

[9] Purwoto. Budi Hari, Jatmiko, Fadilah. Muhamad Aimul, Huda. Ilham Fahmi, "Efisiensi Penggunaan Panel Surya sebagai Sumber Energi Alternatif", Emitor:Jurnal Teknik Elektro, Vol.18 No 1, pp.10-14. 2016.

[10] Indonesia. Government Regulation Number 16 of 2016 on Low Income Community Housing Development. Jakarta: 2016.

[11] Indonesia. Regulation of The Minister of Public Works and Public Housing Number 242/KPTS/M/2020 on Income Limits for the Target Group of Subsidized Home Ownership Loans/Financing, Amount of Interest Rate/Margin of Subsidized Financing, Length of Subsidy Period and Term of Loans/Financing for Home Ownership, Limitation on Selling Price of Landed Public Houses and General Flat Units, Limits on Land Area and House Floor Area of Land House, floor area of public flats and the amount of subsidy for housing down payment. Jakarta: 2020. 